Article

\title{
Sensitivity of Yeast Mutants Deficient in Mitochondrial or Vacuolar ABC Transporters to Pathogenesis-Related Protein TcPR-10 of Theobroma cacao
}

\author{
Louise R. Barreto ${ }^{\dagger}$, Thayná Barreto, Sonia Melo, Cristina Pungartnik * (1) and Martin Brendel \\ Departamento de Ciências Biológicas, Laboratório de Biologia de Fungos, Centro de Biotecnologia e Genética, \\ Universidade Estadual de Santa Cruz (UESC), Rodovia Jorge Amado, km 16, \\ Ilhéus, Bahia, CEP 42665-000, Brazil; loubarreto88@gmail.com (L.R.B.); thaynabarreto1@gmail.com (T.B.); \\ scmelo@uesc.br (S.M.); martinbrendel@yahoo.com.br (M.B.) \\ * Correspondence: cpungartnik@yahoo.com.br; Tel.: +55-74-3680-5438 \\ † Current address: Faculdade Estácio de Feira De Santana, Av. Getúlio Vargas, 3522, Feira de Santana, \\ CEP 44077-005, Brazil.
}

Received: 27 August 2017; Accepted: 1 November 2017; Published: 13 June 2018

\begin{abstract}
Pathogenesis-related proteins (PRs) are induced in plants after infection by pathogens and/or abiotic stress. Among these proteins, the family 10 (PR-10) influences the biosynthesis of secondary metabolites and shows antimicrobial ribonuclease activity. TcPR-10p (Pathogenesis-related Protein 10 of Theobroma cacao) was isolated from resistant and susceptible Moniliophthora perniciosa cacao cultivars. Cell survival with Saccharomyces cerevisiae mutant lines deficient in ATP-binding cassette $(\mathrm{ABC})$ transporter proteins indicated the influence on resistance to TcPR-10p. Proteins of the $\mathrm{ABC}$ transport type are considered important in the process of resistance to antimicrobials and toxins. Thus, the objective of this work was to observe the sensitivity of $\mathrm{ABC}$ transporter yeast mutants in the presence of the TcPR-10p. Chronic exposure of S. cerevisiae mitochondrial (BYatm1 $\Delta$ and BYmdl1 $\Delta$ ) and vacuole (BYnft1 $1 \Delta, \mathrm{BY} v m r 1 \Delta, \mathrm{BY} y b t 1 \Delta, \mathrm{BY} y c f 1 \Delta$ and BYbpt1 $\mathrm{s}) \mathrm{ABC}$ transporter mutants to TcPR-10p ( $3 \mu \mathrm{g} / \mathrm{mL}, 0,6,12$ and $24 \mathrm{~h})$ was performed. Two TcPR-10p sensitive strains (BYmdl1 $\Delta$ and BYnft1 $\Delta$ ) were submitted to a fluorescence test with the fluorogenic dihydroethidium (DHE), to visualize the presence of oxidative stress in the cells. Oxidative stress-increased sensitivity was confirmed by flow cytometry indicating induced cell death either via apoptosis or necrosis. This yeast data combined with previous data of literature (of M. perniciosa sensitivity to TcPR-10p) show that increased sensitivity to TcPR-10p in these mutants could be due to the TcPR10p-generated higher levels of intracellular reactive oxygen species (ROS), leading to increased cell death either via necrosis or apoptosis.
\end{abstract}

Keywords: Saccharomyces cerevisiae; ABC transporters; pathogenesis related protein; PR-10; oxidative stress

\section{Introduction}

Induced after infection by pathogenic agents and/or abiotic stress, pathogenesis related proteins (PRs) were first reported in tobacco mosaic virus infected tobacco plants [1-3]. Currently, it is known that PRs are induced in mono- and eu-dicotyledons when infected by fungi, viruses, bacteria, nematodes, or by insect attack, and in response to defence inducers, i.e., salicylic acid, jasmonic acid, and ethylene [4-6]. They are classified into 17 different families based on sequence homology, serological reactions, enzymatic reactions and biological activities $[2,7]$. 
Amongst the 17 different PR proteins, mechanisms of action and biological implications for members of the PR-10 family are not well comprehended, although they are proposed to have many roles in plants [8]. PR-10 proteins are expressed in conditions of pathogenesis or environmental stresses, suggesting that plant defences could be up-regulated under numerous biotic or abiotic stress disorders; specific proteins also demonstrate antimicrobial or ribonuclease activity [7]. Proteins classified as members of the PR-10 family are constitutively expressed in roots and other plant structures, i.e., stems, flower components, fruits, pollen grains and dried seeds, indicating a central role in growth and general plant development and differentiation [8-11].

PR-10 proteins (PR-10p) are encoded by multi-gene families, featuring the multifunctional aspect of these proteins, which have acquired different mutations and functions during evolution [12,13]. RNase activity of PR-10p was first described in Panax ginseng callus cell culture [14]. Their antifungal activity was identified in proteins expressed in pepper (Capsicum annuum), where hyphal extension of the pathogen Hytophthora capsici was inhibited, and in leaves of the lily Lupinus albus, where PR-10p was induced after infection by the fungus Colletotrichum gloeosporioides $[15,16]$. Recent studies identified DNase activity of PR-10p from rice [17] and grape [18], suggesting nuclease action in the programmed cell death process.

In order to analyse the processes that could involve PR-10 in plant-pathogen interaction, two cDNA libraries from cacao cultivars resistant and susceptible to Moniliophthora perniciosa (the fungus responsible for causing "witches' broom" disease of cacao, Theobroma cacao L.) were constructed [19]. Thus, the gene related to the host resistance response of the cacao plant TcPR-10 (Pathogenesis-Related Protein 10 of Theobroma cacao) could be isolated. TcPR-10p is an acidic protein member of the PR-10 family. Similar genes were discovered in some gymnosperms and angiosperms and have been cloned and described in response to biotic and abiotic stress [20].

The first reported TcPR-10p related activities were demonstrated by the presence of ribonuclease activity against the RNA of the fungus Moniliophthora perniciosa (Stahel), characterized as a doseand time-dependent process. In vitro assays also showed that the presence of TcPR-10p inhibited M. perniciosa growth, indicating antifungal activity [21]. Silva et al. identified in M. perniciosa, increased expression of proteins involved in processes of autophagy, resistance pathogens, and sterol production (important for maintenance of cellular homeostasis in fungi) when grown in contact with TcPR-10p. These facts suggested that the TcPR-10 gene could be used to increase the resistance of plants to pathogens [22]. Experimental results with mutants of the yeast Saccharomyces cerevisiae defect in DNA repair, membrane transporters, metal transporters, and antioxidant defense genes allowed a mechanism of action and active transport of TcPR-10p to be proposed [19,21,22].

The yeast mitochondrial ABC transporter proteins (Mdl1p and Atm1p) are involved in the control of cellular iron homeostasis comprising the biogenesis of iron-sulfur clusters, as well as heme biosynthesis and peptide transport; while the vacuolar ABC transporter proteins (Nft1p, Ycf1p, Bpt1p, Vmr1p and Ybt1p), known as pumps that catalyze the transport of glutathione conjugates to the vacuole in the process of detoxifying the cell from a variety of compounds, including heavy metals, i.e., cadmium and arsenite, are involved in the process of transmembrane transport of substances, autophagy and vacuolar formation; all of them are $\mathrm{ABC}$ transporter proteins and important players in the process of resistance to stress, drugs and toxins [23-25].

Therefore, the objective of this work was not only to continue research on the membrane transport of TcPR-10p, but also to contribute to the improvement in understanding of the effects of TcPR-10p inside the fungal cells. For this purpose, due to the difficulty in manipulating the filamentous fungus $M$. perniciosa, we used mutants of the single cell eukaryote $S$. cerevisiae lacking genes encoding

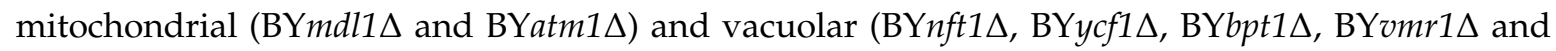
$\mathrm{BY} y b t 1 \Delta) \mathrm{ABC}$ transporter proteins. 


\section{Materials and Methods}

\subsection{Obtaining the TcPR-10 Protein}

The cocoa gene TcPR-10, isolated from the cDNA library of interaction T. cacao $\times$ M. perniciosa, (accession number ES439858), was cloned into expression vector pET28a and the recombinant protein TcPR-10p expressed in Escherichia coli BL21 (DE) as described by Gesteira et al. [19]. TcPR-10p was purified and quantified using Bradford assay with a minimum of three different replicates prior to realizing the experiments.

\subsection{Growth Conditions of Yeast S. cerevisiae}

The S. cerevisiae strains used in this work are listed in Table 1. Media, solutions and buffers were prepared according to Burke et al. [26]. To obtain yeast cells in stationary growth phase (STAT cells, density of approximately $2 \times 10^{8}$ cells $/ \mathrm{mL}$ ), stock aliquots in glycerol were inoculated in rich medium (YPD-10 g/L extract yeast; $20 \mathrm{~g} / \mathrm{L}$ Bacto Peptone; $20 \mathrm{~g} / \mathrm{L}$ dextrose) and incubated under constant aeration in a gyratory shaker (New Brunswick, G-76) for 2-3 days, or in solid medium YPD (YEL + $20 \mathrm{~g} / \mathrm{L}$ agar) at $28^{\circ} \mathrm{C}$. Cells in exponential growth phase (LOG cells) were obtained by 5 to $12 \mathrm{~h}$ of incubation at $28{ }^{\circ} \mathrm{C}$ under constant aeration in a gyratory shaker (New Brunswick, G-76, $180 \mathrm{rpm}$ ), reaching 1 to $2 \times 10^{7}$ cells $/ \mathrm{m}$. A culture was considered in LOG phase when at least $30 \%$ of the cells were budding. To ascertain their respiratory competence and eliminate spontaneously accumulated petites, all strains were pre-grown on solid YPG medium (YPD in which glucose was replaced by $2 \%$ glycerol) before being used for experimentation. Experiments were done at least three times in triplicate.

Table 1. Yeast strains, genotype and related function.

\begin{tabular}{|c|c|c|}
\hline Strains * & Genotype & Name Description/Cellular Component ** \\
\hline $\begin{array}{l}\text { BY4742 } \\
\text { (WT) }\end{array}$ & $\begin{array}{c}\text { MAT } \alpha \text { his } 3 \Delta 1 \text { leu } 2 \Delta 0 \text { lys } 2 \Delta 0 \\
\text { ura } \Delta 00\end{array}$ & Wild type for $A B C$ transporters \\
\hline BYmdl1 $\Delta$ & Same as WT, YLR188w deleted & $\begin{array}{l}\text { Multi-Drug resistance-Like/Mitochondrial inner membrane } \\
\text { half-type ABC transporter; mediates export of peptides } \\
\text { generated upon proteolysis of mitochondrial proteins; plays a } \\
\text { role in the regulation of cellular resistance to oxidative stress }\end{array}$ \\
\hline BYatm1 $1 \Delta$ & Same as WT, YMR301c deleted & $\begin{array}{l}\text { ABC Transporter, Mitochondria/Mitochondrial inner } \\
\text { membrane ATP-binding cassette (ABC) transporter; exports } \\
\text { mitochondrially synthesized precursors of iron-sulfur (Fe/S) } \\
\text { clusters to the cytosol }\end{array}$ \\
\hline $\mathrm{BY} y b t 1 \Delta$ & Same as WT, YLL048c deleted & $\begin{array}{l}\text { Yeast Bile Transporter/Transporter of the ATP-binding } \\
\text { cassette (ABC) family; negative regulator of vacuole fusion }\end{array}$ \\
\hline BYnft1 & Same as WT, YKR103w deleted & $\begin{array}{c}\text { New Full-length MRP-type Transporter/Transporter of the } \\
\text { ATP-binding cassette (ABC) vacuole; multidrug } \\
\text { resistance-associated protein }\end{array}$ \\
\hline BYyct1 $1 \Delta$ & Same as WT, YLL055w deleted & $\begin{array}{l}\text { Yeast Cysteine Transporter/Transporter of the ATP-binding } \\
\text { cassette (ABC) vacuole; High-affinity } \\
\text { cysteine-specific transporter }\end{array}$ \\
\hline BYbpt1D & Same as WT, YLL015w deleted & $\begin{array}{c}\text { Bile Pigment Transporter/ABC type transmembrane } \\
\text { transporter of MRP/CFTR family; found in vacuolar } \\
\text { membrane, involved in the transport of unconjugated } \\
\text { bilirubin and in heavy metal detoxification via glutathione } \\
\text { conjugates, along with Ycf1p }\end{array}$ \\
\hline BYvmr1s & Same as WT, YHL035c deleted & $\begin{array}{c}\text { Vacuolar Multidrug Resistance/Vacuolar membrane protein; } \\
\text { involved in multiple drug resistance and metal sensitivity; } \\
\text { ATP-binding cassette (ABC) family member involved in } \\
\text { drug transport }\end{array}$ \\
\hline
\end{tabular}

* All strains are from EUROSCARF; ** http:/ / www.yeastgenome.org. 


\subsection{Yeast Survival after TcPR-10p Exposure}

For treatment with TcPR-10p, cells in LOG cells $\left(\mathrm{OD}_{660}\right.$ between 1.2 to $2.4 \times 10^{7}$ cells $\left./ \mathrm{mL}\right)$ were centrifuged at $5000 \mathrm{~g}$ for $5 \mathrm{~min}$ and suspended in $50 \mathrm{mM}$ sodium phosphate buffer ( $\mathrm{pH}$ 7.4). Cell titre of approximately $10^{5}$ cells $/ \mathrm{mL}$ was determined by absorbance reading $(660 \mathrm{~nm})$ in a Spectrophotometer V-1600 ${ }^{\circledR}$ (Roctec Technology, Hong Kong, China) [26]. Aliquots were treated with the same dose as described in previous studies, i.e., $3 \mu \mathrm{g} / \mathrm{mL} \mathrm{TcPR}-10 \mathrm{p}$ at $25^{\circ} \mathrm{C}$ for exposure times $0,1.53,6,12$ and $24 \mathrm{~h}$. The samples were properly diluted, plated on YPD agar and tested for cell survival after 3 days of incubation at $28^{\circ} \mathrm{C}$.

Cell survival was calculated once counting the number of colonies grown on the plates following $3 \mathrm{~d}$ of growth at $28^{\circ} \mathrm{C}$ and calculating the fraction of TcRP-10p-exposed survival in relation to the zero dose and expressed as a percentage $(\mathrm{N} / \mathrm{No} \times 100)$. The measurement of the effect of TcPR-10p using the percentage survival vs. dose with a logarithmic ordinate was visualized using a typical inactivation kinetics curve, where the rate of decrease of the number of active single yeast cells with respect to dose is proportional to the number of active cells remaining at that dose level [27]. When killing follows single hit kinetics, the inactivation curve is exponential, and the graph will yield a linear curve with a negative slope in a semi-log plot. Survival is presented in a semi-log graph to enable rapid estimation of the dose reduction factor [28]. Statistical analysis between parallel experiments was performed using the standard deviation, using the GraphPad Prism ${ }^{\circledR}$ program (GraphPad Software Incorporation, San Diego, CA, USA).

Graphs were generated using the GraphPad Prism ${ }^{\circledR}$ program (GraphPad Software Incorporation, San Diego, CA, USA); error bars represent the standard deviations of at least three independent experiments, in triplicate.

\subsection{Fluorescence Assay of TcPR-10p Yeast Mutants}

Mutant strains in LOG phase were treated with $3 \mu \mathrm{g} / \mathrm{mL}$ of TcPR-10p for 6 and $24 \mathrm{~h}$. Thereafter, cells were washed with saline solution $(\mathrm{NaCl} 0.9 \%)$ and suspended in a final volume of $1 \mathrm{~mL}$. A stock solution $\left(1 \mathrm{mg} / \mathrm{mL}\right.$ ) of the fluorogenic probe dihydroethidium (DHE, SIGMA-ALDRICH ${ }^{\circledR}$, St. Louis, MO, USA) was prepared by dissolving it in dimethyl sulfoxide (Sigma, St. Louis, MO, USA). One mL of yeast cells was stained with the addition of $1 \mu \mathrm{L}$ of stock solution, mixed by inversion, incubated for $30 \mathrm{~min}$ at $28^{\circ} \mathrm{C}$, washed three times with saline, and re-suspended in $100 \mu \mathrm{L}$ of saline. An aliquot was used to determine the oxidative/reductive stress of the cells. Cytosolic DHE can be oxidized by reactive oxygen species (ROS, i.e., singlet oxygen, hydroxyl radicals, superoxide, hydroperoxides and peroxides) to form ethidium, which intercalates with the cellular DNA and brightly fluoresces red $(\lambda=605 \mathrm{~nm})$ [29]. ROS induction was observed by fluorescence microscopy DMRA2 (Leica ${ }^{\circledR}$, Wetzlar, Germany) using a DHE filter. Images were captured using a $40 \times$ objective under bright field and using fluorescent filters with the IM50 software $\left(\right.$ Leica $\left.^{\circledR}\right)$. Photos represent one sample from at least three independent experiments.

\subsection{Flow Cytometry}

Yeasts mutants that showed sensitivity at the survival curve and presence of oxidative stress by the DHE assay underwent cell death assessment through Cell Cytometry using two different dyes to Alexa Fluor ${ }^{\circledR} 488$ annexin V, which allows the labelling of phosphatidylserine (PS), exposed by the cell during the apoptosis process, and propidium iodide (PI), an impermeable dye that allows the integrity of the cytoplasmic membrane to be evaluated. LOG phase cells (OD660 between 1.2 to $2.4 \times 10^{7}$ cells $\left./ \mathrm{mL}\right)$ were treated with TcPR-10 for $24 \mathrm{H}(3 \mu \mathrm{g} / \mathrm{mL})$, then cells were washed with 50 $\mathrm{mM}$ sodium phosphate buffer ( $\mathrm{pH}$ 7.4), centrifuged at $5000 \mathrm{~g}$ for $5 \mathrm{~min}$. This process was repeated 3 to 4 times, and cells were suspended in the final volume of $500 \mu \mathrm{L}$ with $50 \mathrm{mM}$ sodium phosphate buffer ( $\mathrm{pH}$ 7.4). The cells were then labelled, according to the manufacturer's instructions, using the Anexinn V-FITC/PI kit (Beckman Coulter) and read (50,000 acquisitions/tube) on the FC 500 flow cytometer 
(Beckman Coulter) in order to evaluate the percentage of cells in apoptosis. Experiments were done in triplicate.

\subsection{Analysis of Results}

All experiments were performed in triplicate and expressed with mean and standard deviation. Mean-variance analysis tests were performed by the Graph Pad Prism ${ }^{\circledR}$ program (Graph Pad Software, Inc., San Diego, CA, USA).

\section{Results}

\subsection{Yeast Survival after Exposure to TcPR-10p}

The mitochondrial transporter ABC proteins Mdl1p and Atm1p are implicated in the regulation of cellular iron homeostasis, comprising the biogenesis of iron-sulphur clusters [24]. LOG phase cells of the BYmdl1 $\Delta$ mutant exposed to $3 \mu \mathrm{g} / \mathrm{mL}$ TcPR-10p exhibit significant increases in sensitivity, while equally treated BYatm $1 \Delta$ mutant cells were more resistant when compared to the equally treated wild type (WT) (Figure 1).

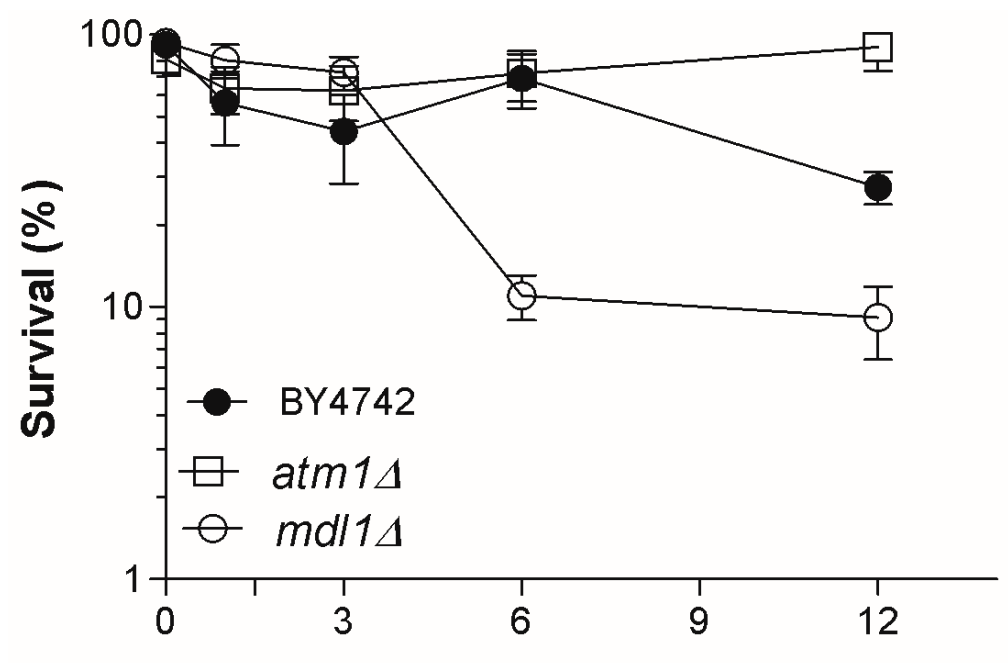

Exposure to $3 \mu \mathrm{g} / \mathrm{mL}$ TcPR- 10 (h)

Figure 1. Survival of LOG phase mitochondrial ABC transporter-deficient S. cerevisiae mutants when exposed to $3 \mu \mathrm{g} / \mathrm{mL}$ of TcPR-10p. Result expressed with mean deviation and standard deviation of three independent experiments.

Survival graph of the five TcPR-10p -exposed mutant strains BYnft1 $\triangle$, BYycf1 $1 \Delta, \mathrm{BY} b p t 1 \Delta, \mathrm{BY} v m r 1 \Delta$ and $B Y y b t 1 \triangle$, each lacking a specific $A B C$ transporter protein located in the vacuolar membrane is shown in Figure 2. The survival profile of LOG phase yeast cells exposed to $3 \mu \mathrm{g} / \mathrm{mL}$ TcPR-10p in show that only one of the five tested mutant, BYnft1 $\Delta$ presents significantly increased sensitivity when compared to equally treated WT strain.

To facilitate the perception of sensitivity, a drop survival curve was performed with the two mutant strains tested that showed higher sensitivity after exposure with $3 \mu \mathrm{g} / \mathrm{mL}$ of TcPR-10p when compared to the WT BY4742 strain. The test clearly shows greater sensitivity of the two mutant strains after $6 \mathrm{~h}$ of exposure (Figure 3). 


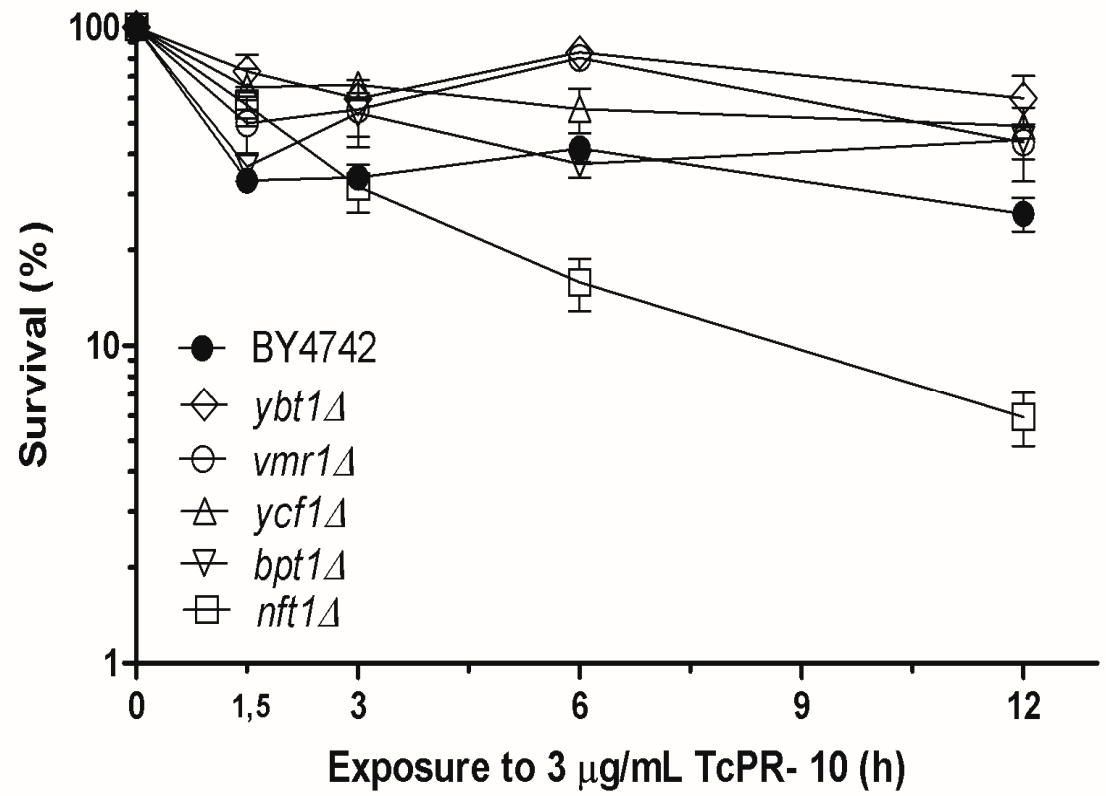

Figure 2. Survival of LOG phase wild-type (WT) and five isogenic yeast Saccharomyces cerevisiae vacuolar $\mathrm{ABC}$ transporter- deficient mutants exposed to $3 \mu \mathrm{g} / \mathrm{mL}$ of TcPR-10p ( 0 to $12 \mathrm{~h}$ ). Results expressed with mean deviation and standard deviation of three independent experiments.

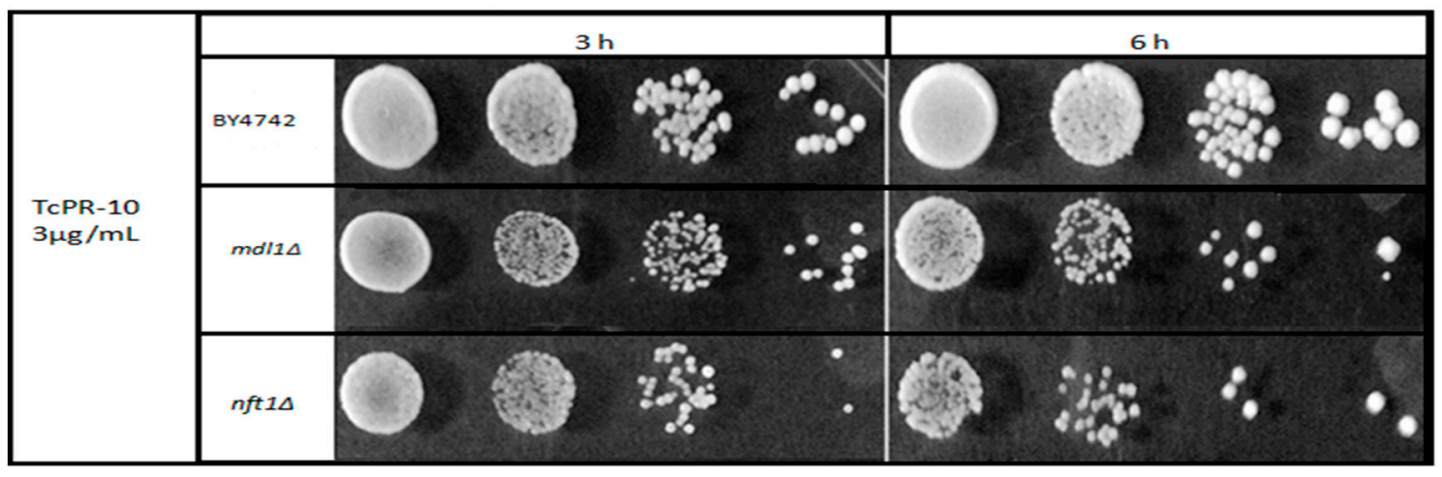

Figure 3. Sensitivity of yeast mutants lacking either mitochondrial (Mdl1p) or vacuolar (Nft1p) ABC transporter proteins after 3 and $6 \mathrm{~h}$ exposure to $3 \mu \mathrm{g} / \mathrm{mL}$ TcPR-10p.

\subsection{Yeast Sensitive Mutants Show Increased ROS Levels Induced by TcPR-10p}

Specific sensitivity of two out of seven ABC transporter mutants could be due to the fact that TcPR-10p is able to induce oxidative stress [20-22]. The images obtained after marking with DHE show the increased ROS generated after exposure to TcPR-10p for 6 and $24 \mathrm{~h}$ of yeast mutants BYmdl1 $\Delta$ and BYnft1 $\Delta$ strains when compared to WT (Figure 4).

The stress responses of WT BY4742 and mutant BYmdl1 $\Delta$ increases with exposure time as can be observed by the correlation of free radical presence with time of exposure. In contrast, the strain BYnft1 $\Delta$ (disabled in the process of autophagy) already has high initial ROS levels but still shows even higher ROS levels after $24 \mathrm{~h}$ of TcPR-10p exposure. 


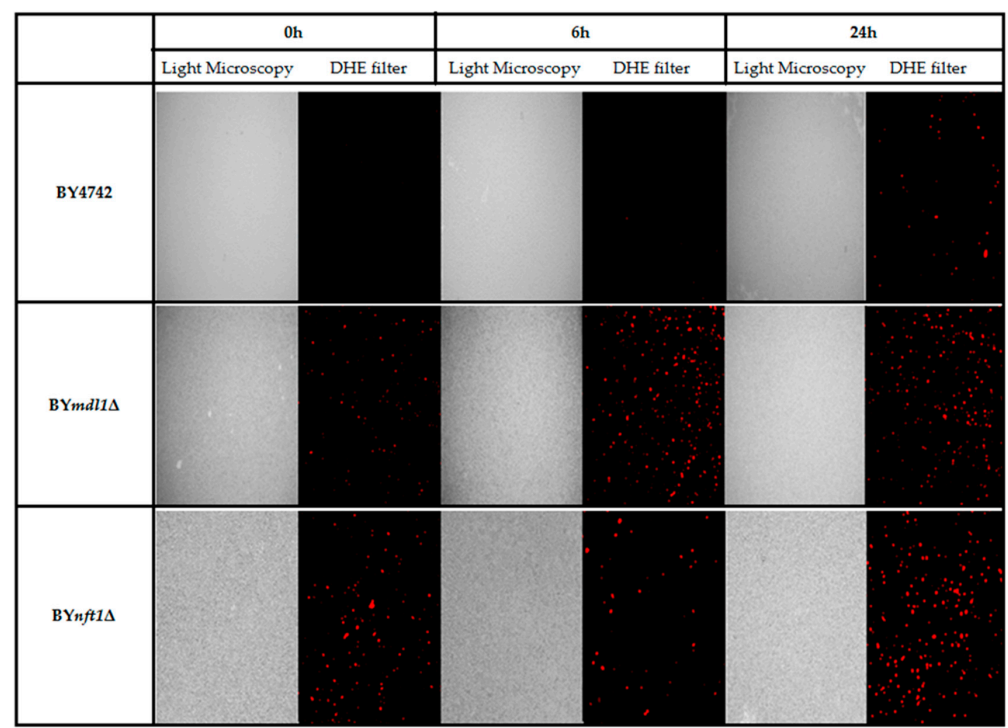

Figure 4. TcPR-10p induced ROS in isogenic S. cerevisiae strains: WT, BYmdl1 $\Delta$ and BYnft1 $\Delta$ treated with $3 \mu \mathrm{g} / \mathrm{mL}$ TcPR-10p for 6 and $24 \mathrm{~h}$ and observed by fluorescence microscopy (DHE filter).

\subsection{Flow Cytometry Assay of TcPR-10p Sensitive Yeast Mutants}

The increased sensitivity associated with oxidative stress induced by TcPR-10p in ABC transporter mutants with different phenotypes and different $\mathrm{ABC}$ transporter membrane location BYmdl1 $\triangle$ (mitochondria) and BYnft1 (vacuole) could trigger different metabolic responses. Therefore, we analyzed via the flow cytometry technique, DNA fragmentation (apoptosis-Anexin V), cell viability (necrosis-PI), and double labelling with annexin V conjugated to FITC and propidium iodide (apoptosis and necrosis) (Figure 5, Supplementary Table S1). In the mutant yeast strains BY4742 and BYmd1l $\Delta$, an increased number of apoptotic cells after TcPR-10p was observed when compared to the respective controls. For the BYnft1 $\Delta$ mutant it was possible to observe the presence of three times more cells in necrosis when exposed to TcPR-10p than the control group, according to Figure 5 and Supplementary Table S1.

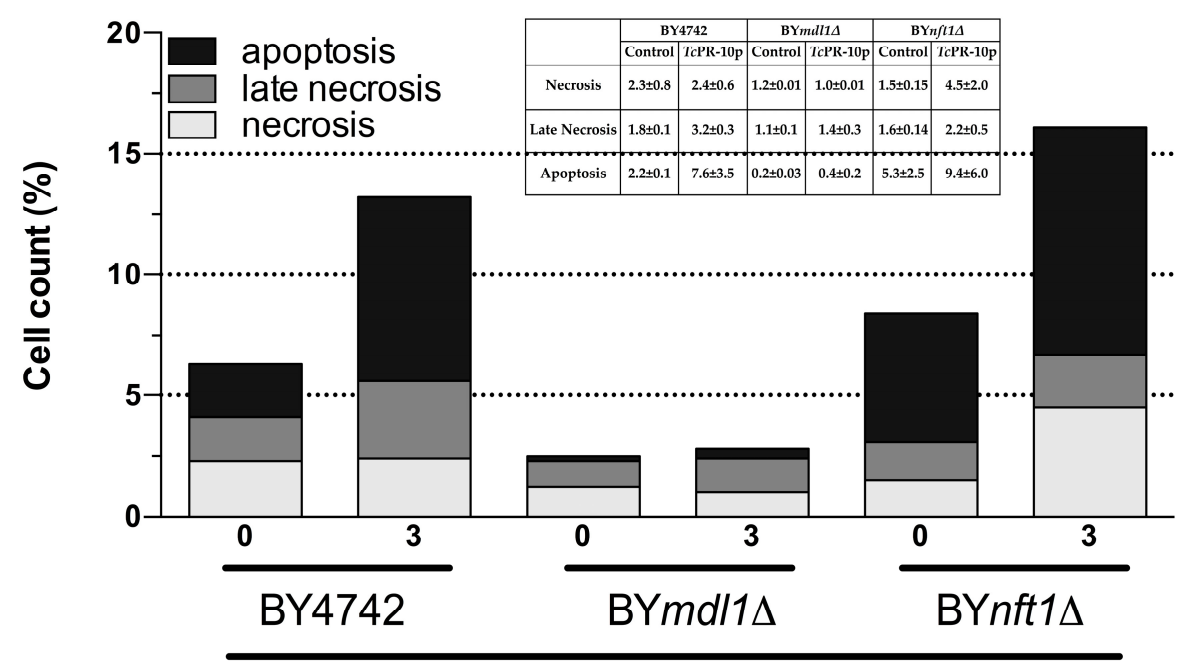

$\operatorname{TcPr}-10 \mathrm{p}(\mu \mathrm{g} / \mathrm{mL}, 24 \mathrm{~h})$

Figure 5. Flow cytometry assay of isogenic $S$. cerevisiae yeast strains treated with $3 \mu \mathrm{g} / \mathrm{mL}$ TcPR-10p for $24 \mathrm{~h}$. WT BY4742; BYmdl1 $\Delta$; and BYnft1 $\Delta$. (one figure representative of scatter plots formed from bi-parametric analysis). 


\section{Discussion}

The pathogenesis-related protein PR-10 is produced in plants under conditions of stress or after infection. TcPR-10p is a member of the acidic protein family PR-10 [20]. Isolated from M. perniciosa resistant T. cacao cultivars it was characterized as having RNase activity, causing oxidative stress and promoting the death of pathogens in a response of plant defence [19,30-32].

The cellular plasma membrane and membranes of different organelles contain transporter proteins of the $A B C$ type that are involved in the processes of resistance and sensitivity of the pathogen to certain host defence toxins [33]. Yeast mutants lacking ABC transporters of the plasma membrane were tested for sensitivity to TcPR-10p in an attempt to elucidate the transport routes and mode of action of this protein inside the cells [21,22]. Among the tested ABC transporter-deficient mutant strains, BYsnq2 $\Delta$ and BYpdr11 $\Delta$ exhibited a TcPR-10p sensitivity profile as compared to the isogenic WT. These results indicate that the sensitivity of the fungus to TcPR-10p comprises numerous biochemical routes, elucidating the probable types of action of this antifungal protein [21,22].

As for our current research, we used WT strain BY4742 and different isogenic mutants, each lacking one $\mathrm{ABC}$ transporter-coding gene of different subfamilies located in mitochondria (BYatm1 $\Delta$

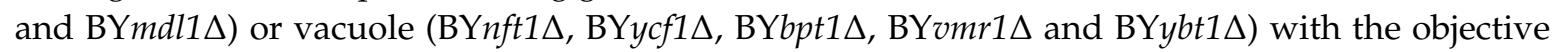
of evaluating the possible interaction of intracellular TcPR-10p, imported via a plasma membrane with the WT composition of $\mathrm{ABC}$ transporters, with mitochondria and vacuoles lacking one defined ABC transporter protein. Such organelle membrane deficiency could lead to an altered phenotype, revealed as a change in yeast cell sensitivity to TcPR-10p [34].

Both Atm1 and Mdl1 proteins are located in the inner mitochondrial membrane with the ATP binding domain oriented to the matrix, and have an important role in mitochondrial export [24,35]. Atm1p is a cellular iron homeostasis regulator, and its absence causes an increased accumulation of iron and oxidized glutathione in a stress process caused by a Fenton reaction [23,36]. The presence of Mdl1p is able to complement the absence of Atm1p [37]. This feature keeps the mitochondrial export in mutant BYatm1 $\Delta$ active, which may explain the observed WT-like or more resistant survival profile of TcPR-10p treated atm1 $\Delta$ mutant (Figure 1).

Increased sensitivity of the BYmdl1 $\Delta$ mutant to TcPR-10p may be related to characteristics of the absence of this protein related to oxidative stress. Mdl1p accounts for the export of peptides produced after proteolysis of mitochondrial proteins; and also plays a significant role in the regulation of cellular resistance to oxidative stress [38]. BYmdl1 $\Delta$ mutant shows a $40 \%$ reduction in the release of peptides generated by mitochondrial proteases [24]. Besides having binding sites for fatty acids, flavonoids, cytokines and sterols, TcPR-10p has been associated with ribonuclease activity. An increase in degraded RNA promotes intracellular oxidative stress by the formation of free radicals that may also act as marker for cell death [39]. Therefore, the combination of increased malformed peptides (accumulated inside the organelle leading to stress signals due to the absence of peptide export) and the presence of free radicals (formed by accumulation of degraded RNA) may both be responsible for the increased cell death after $6 \mathrm{~h}$ of TcPR-10p exposure in the Mdl1p-lacking mutant (Figure 1).

Vacuoles are compartments participating in important physiological processes of yeast cells, such as: storage of nutrients, autophagy, degradation of cell compounds, and also recycling of proteins $[25,40]$. The $\mathrm{ABC}$ transporter-dependent vacuolar sequestration of unwanted cellular molecules is an important recycling and detoxification mechanism [40]. Applying phylogenetic analysis Wawrzycka et al. [41] divided vacuole-located ABC transporter type proteins into three groups: Cluster 1: Ybt1p (bile acid transporter and negative regulator in vacuole formation) and its homologue Vmr1p (transport of conjugated DNP-S-glutathione, export S-(2,4-dinitrophenyl)-glutathione); Cluster 2: Ycf1p and its homologue Bpt1p (pumps responsible for catalysing glutathione transport and detoxifying the cell of a variety of heavy metals, i.e., cadmium and arsenate), and Nft1p (responsible for autophagy); and Cluster 3: comprises only Yor1p (not included in our study). The same study showed the existence of homology between the Vmr1 and Ybt1 proteins and their functional interactions [42,43]. 
Out of five vacuolar yeast mutants, four had slightly increased resistance to TcPR-10p under the tested conditions when compared to the respective WT (Figure 2). Yeast Ybt1p is a negative regulator of vacuole formation, and in its absence, a larger number of vacuoles are formed, reducing stress [41]. Ybt1p and Vmr1p are homologues; the same study showed the existence of homology between the Vmr1 and Ybt1 proteins and their functional interactions, and a conjugate of a protein was used as substrate to mediate the transport of another [42,43]. Likewise, Ycf1p reduces basal level of oxidative stress reaction in S. cerevisiae [43]. This WT-like resistance of each one of the vacuole ABC transporter-lacking mutants BYycf1 $\Delta, \mathrm{BY} b p t 1 \Delta, \mathrm{BY} v m r 1 \Delta$ and BYybt1 $\Delta$ that are homologous to each other was expected (Figure 2).

In contrast, the absence of vacuolar Nft1p leads to a decrease in autophagic activity, which is important for cell degradation processes, and maintenance of homeostasis and lipid transport to the expanding membrane during the process of membrane closure $[25,40]$. The ribonuclease activity of TcPR-10p degrades nucleic acids, thereby inducing oxidative stress [21,22]. Thus, with reduced autophagy, the recycling of intracellular accumulated unwanted stress-causing compounds is decreased; this sensitizes only BYnft1 $\Delta$ mutant cells to the ROS generated by TcPR-10p, leading to the observed increased cell death (Figures 2 and 3).

In order to confirm that ROS generated by TcPR-10p could be the culprit and influence sensitivity of both BYmdl1 $\Delta$ and BYnft1 $\Delta$ mutants, DHE was used to observe induced ROS formation after TcPR-10p exposure under same conditions of the survival (Figure 4). The proportional increase of ROS in BYmdl1 $\Delta$ mutant cells to TcPR-10p exposure time is clearly observable under fluorescence microscopy images (Figure 4). In BYnft1 $\Delta$ mutant cells, with reduced ability of autophagy, it is possible to observe increased oxidative stress at all exposure times (6 and $24 \mathrm{~h})$. Yet, the reduction of autophagic activity [44] seems to be related to the presence of high levels of ROS in the BYnft1 $\Delta$ mutant (Figure 4), and to sensitivity observed in the survival tests (Figures 2 and 3).

Members of the PR-10 family of proteins have been reported for playing a crucial role during the attack of a pathogen by activating apoptotic processes in the pathogen, thus limiting the success of the invasion [45]. Indeed, in yeast strains BY4742 and BYmd1ls, an increased number of apoptotic cells after TcPR-10p is observed when compared to the respective controls, while for the BYnft1 $1 \Delta$ mutant, it is possible to observe the presence of three times more cells in necrosis when exposed to TcPR-10p than the control group according to Figure 5.

Until now, there is only a limited number of factors, i.e., ageing, mating, or exposure to killer toxins and the application of acetic acid, antifungal peptides, hydrogen peroxide, and oxygen radicals, known to induce programmed cell death in yeast $[46,47]$. Our data obtained from this study suggest that absence of Mdl1p (mitochondrial $\mathrm{ABC}$ transporter protein responsible for monitoring resistance to oxidative stress) leads to cellular death by apoptotic pathway as presence of TcPR-10p causes increased oxidative stress verified by high levels of intracellular ROS (Figures 4 and 5), while in BYnft1 $\Delta$ mutant leads to cellular death by necrosis. Numerous studies on apoptosis point to mitochondria as the main mediator of cell death. This organelle integrates cell death stimuli, inducing mitochondrial permeabilization, which results in release of pro-apoptotic molecules [48]. In addition to leaking molecules, induced collapse of potential of the inner mitochondrial membrane leads to loss of cellular homeostasis, interrupting ATP synthesis and increasing ROS production $[49,50]$.

\section{Conclusions}

Apart from well-confirmed RNase activity of PR-10p in different organisms, including M. perniciosa, studies that identified DNase activity in rice and grape likewise suggested nuclease action in apoptosis. Additionally, many proteins associated with detoxification, autophagy, or that were involved in mechanisms for maintaining fungal homeostasis (such as ergosterol biosynthesis) were induced by TcPR-10, as shown by proteomics analysis, a fact that is coherent with the antifungal activity of TcPR-10. Recently, we could also observe changes in cellular infrastructure after induced 
endoplasmic reticulum (ER) stress in M. perniciosa, i.e., remodelling of the ER under stress, formation of ER-phagy, and induction of apoptosis after severe ER stress.

Mutants of $S$. cerevisiae that lack mitochondrial ABC transporter protein Mdl1p or vacuolar ABC transporter Nft1p showed increased stress sensitivity to TcPR-10p exposure when compared to the isogenic WT. However, this was most probably due to different biochemical mechanism of action, since TcPR-10p treated BYmd1l $\Delta$ mutant showed increased numbers of apoptotic cells, while for the equally treated BYnft1 $\Delta$ mutant a higher number of necrotic cells were observed. This yeast data, combined with previous data of literature (of M. perniciosa sensitivity to TcPR-10p), shows that yeast increased sensitivity to TcPR-10p could be due to the higher levels of intracellular ROS generated by the TcPR10p, in these mutants, which would lead to increased cell death either via necrosis or apoptosis.

This study attempts to clarify the mode of action of the T. cacao defence protein TcPR-10p using the yeast $S$. cerevisiae as a research model. The obtained data may help us to understand the effects of TcPR-10p on multicellular fungal phytopathogens such as M. perniciosa, a basidiomycete fungus that, by causing "witches' broom" disease in T. cacao, leads to substantial economic loss in cacao production. Nevertheless, supplementary experiments in planta are necessary to understand the mechanisms of resistance of this fungus to the plant defence mechanism. A better understanding of the fungal resistance to oxidative stress may give us the means to weaken the efficiency of this process and enhance the plant's chances to fight fungal infection.

Supplementary Materials: The following are available online at http:/ / www.mdpi.com/2079-7737/7/2/35/s1: Table S1: Statistical analysis of data of Figure 5. Two way ANOVA, Sidak's and Tukey's multiple comparison test.

Author Contributions: C.P., M.B. and S.M. conceived and designed the experiments; L.R.B. and T.B. performed the experiments; all authors analysed the data; C.P., M.B. and S.M. wrote and critically analysed the paper.

Acknowledgments: Louise R. Barreto was a master student of Programa de Pós-graduaçao em Biologia e Biotecnologia de Microrganismos at UESC and held a FAPESB fellowship, Thayná Barreto was scientific initiation student with a CNPq fellowship, Cristina Pungartnik held a CNPq (Conselho Nacional de Desenvolvimento Científico e Tecnológico) fellowship. Martin Brendel held a FAPESB fellowship (Fundação de Apoio a Pesquisa no Estado da Bahia). Research was supported by grants from CNPq and FAPESB. Please provide full name. We would like to thank Carla C. Romano and Tauá Melo for helping us with the flow cytometry experiments.

Conflicts of Interest: The authors declare no conflict of interest.

\section{Abbreviations}

WT, wild type like strain. TcPR-10p, pathogenesis-related protein 10 of Theobroma cacao. PR, pathogenisis-related protein. ABC transporter, ATP binding cassette transporter. MRP/CFTR, cystic fibrosis transmembrane conductance regulator, ATP-binding cassette, sub-family C, CFTR is a member of the MRP (multidrug resitance proteins) subfamily that is involved in multi-drug resistance. PI, propidium iodide. FITC, Fluorescein isothiocyanate.

\section{References}

1. Zhao, J.; Davis, L.C.; Verpoorte, R. Elicitor signal transduction leading to production of plant secondary metabolites. Biotechnol. Adv. 2005, 23, 283-333. [CrossRef] [PubMed]

2. Van Loon, L.; Rep, M.; Pieterse, C. Significance of inducible defense-related proteins in infected plants. Annu. Rev. Phytopathol. 2006, 44, 135-162. [CrossRef] [PubMed]

3. Sels, J.; Mathys, J.; De Coninck, B.M.; Cammue, B.P.; De Bolle, M.F. Plant pathogenesis-related (PR) proteins: A focus on PR peptides. Plant Physiol. Biochem. 2008, 46, 941-950. [CrossRef] [PubMed]

4. Doornbos, R.F.; Geraats, B.P.; Kuramae, E.E.; Van Loon, L.C.; Bakker, P.A. Effects of jasmonic acid, ethylene, and salicylic acid signaling on the rhizosphere bacterial community of Arabidopsis thaliana. Mol. Plant Microbe Interact. 2011, 24, 395-407. [CrossRef] [PubMed]

5. García-Cristobal, J.; García-Villaraco, A.; Ramos, B.; Gutierrez-Mañero, J.; Lucas, J.A. Priming of pathogenesis related-proteins and enzymes related to oxidative stress by plant growth promoting rhizobacteria on rice plants upon abiotic and biotic stress challenge. J. Plant Physiol. 2015, 188, 72-79. [CrossRef] [PubMed]

6. Karppinen, K.; Derzsó, E.; Jaakola, L.; Hohtola, A. Molecular Cloning and Expression Analysis of hyp-1 Type PR-10 Family Genes in Hypericum perforatum. Front. Plant Sci. 2016, 7, 526. [CrossRef] [PubMed] 
7. Agarwal, P.; Agarwal, P.K. Pathogenesis related-10 proteins are small, structurally similar but with diverse role in stress signaling. Mol. Biol. Rep. 2014, 41, 599-611. [CrossRef] [PubMed]

8. Fernandes, H.; Michalska, K.; Sikorski, M.; Jaskolski, M. Structural and functional aspects of PR-10 proteins. FEBS J. 2013, 280, 1169-1199. [CrossRef] [PubMed]

9. Breda, C.; Sallaud, C.; El-Turk, J.; Buffard, D.; De Kozak, I.; Esnault, R.; Kondorosi, A. Defense reaction in Medicago sativa: A gene encoding a class $10 \mathrm{PR}$ protein is expressed in vascular bundles. Mol. Plant Microbe Interact. 1996, 9, 713-719. [CrossRef] [PubMed]

10. Sikorski, M.M.; Biesiadka, J.; Kasperska, A.E.; Kopcinska, J.; Lotocka, B.; Golinowski, W.; Blegocki, A. Expression of genes encoding PR10 class pathogenesis-related proteins is inhibited in yellow lupine root nodules. Plant Sci. 1999, 149, 125-137. [CrossRef]

11. Puhringer, H.; Moll, D.; Hoffmann-Sommergruber, K.; Watillon, B.; Katinger, H.; Machado, M.L.D. The promoter of an apple Ypr10 gene, encoding the major allergen Mal d 1, is stress- and pathogen-inducible. Plant Sci. 2000, 152, 35-50. [CrossRef]

12. Tokuriki, N.; Tawfik, D.S. Protein dynamism and evolvability. Science 2009, 324, 203-207. [CrossRef] [PubMed]

13. Franco, O.L. Peptide promiscuity: An evolutionary concept for plant defense. FEBS Lett. 2011, 585, 995-1000. [CrossRef] [PubMed]

14. Moiseyev, G.P.; Beintema, J.J.; Fedoreyeva, L.I.; Yakovlev, G.I. High sequence similarity between a ribonuclease from ginseng calluses and fungus-elicited proteins from parsley indicates that intracellular pathogenesis-related proteins are ribonucleases. Plant 1994, 193, 470-472. [CrossRef]

15. Pinto, M.P.; Ricardo, C.P. Lupinus albus L. pathogenesis-related proteins that show similarity to PR-10 proteins. Plant Physiol. 1995, 109, 1345-1351. [CrossRef] [PubMed]

16. Park, C.J.; Kim, K.J.; Shin, R.; Park, J.M.; Shin, Y.C.; Paek, K.H. Pathogenesis-related protein 10 isolated from hot pepper functions as a ribonuclease in an antiviral pathway. Plant J. 2004, 37, 186-198. [CrossRef] [PubMed]

17. Kim, J.; Klionsky, D.J. Autophagy, cytosplasm-to-vacuole targeting pathway, and perophagy in yeast and mammalian cells. Annu. Rev. Biochem. 2000, 69, 303-342. [CrossRef] [PubMed]

18. He, M.; Xu, Y.; Cao, J. Subcellular localization and functional analyses of a PR10 protein gene from Vitis pseudoreticulata in response to Plasmopara viticola infection. Protoplasma 2013, 250, 129-140. [CrossRef] [PubMed]

19. Gesteira, A.S.; Micheli, F.; Carels, N.; Da Silva, A.C.; Gramacho, K.P.; Schuster, I.; Macêdo, J.N.; Pereira, G.A.; Cascardo, J.C. Comparative analysis of expressed genes from cacao meristems infected by Moniliophthora perniciosa. Ann. Bot. 2007, 100, 129-140. [CrossRef] [PubMed]

20. Jain, S.; Kumar, A. The Pathogenesis Related Class 10 proteins in Plant Defense against Biotic and Abiotic Stresses. Adv. Plants Agric. Res. 2015, 3, 00077. [CrossRef]

21. Pungartnik, C.; Da Silva, A.C.; De Melo, S.A.; Gramacho, K.P.; Mattos Cascardo, J.C.; Brendel, M.; Micheli, F.; Gesteira, A. High-affinity copper transport and Snq2 export permease of Saccharomyces cerevisiae modulate cytotoxicity of PR-10 from Theobroma cacao. Mol. Plant Microbe Interact. 2009, 22, 39-51. [CrossRef] [PubMed]

22. Silva, F.A.C.; Pirovani, C.P.; Menezes, S.; Pungartnik, C.; Santiago, A.S.; Costa, M.G.C.; Micheli, F.; Gesteira, A.S. Proteomic response of Moniliophthora perniciosa exposed to pathogenesis-related protein-10 from Theobroma cacao. Gen. Mol. Res. 2013, 12, 4855-4868. [CrossRef] [PubMed]

23. Li, J.; Kogan, M.; Knight, S.S.B.; Pain, D.; Dancis, A. Yeast Mitochondrial Protein, Nfs1p, Coordinately Regulates Iron-Sulfur Cluster Proteins, Cellular Iron Uptake, and Iron Distribution. J. Biol. Chem. 1999, 274, 33025-33034. [CrossRef] [PubMed]

24. Young, L.; Leonhard, K.; Tatsuta, T.; Trowsdale, J.; Langer, T. Role of the ABC transporter Mdl1 in peptide export from mitochondria. Science 2011, 291, 2135-2138. [CrossRef] [PubMed]

25. Klionsky, D.J.; Baehrecke, E.H.; Brumell, J.H.; Chu, C.T.; Codogno, P.; Cuervo, A.M.; Debnath, J.; Deretic, V.; Elazar, Z.; Eskelinen, E.L.; et al. A comprehensive glossary of autophagy-related molecules and processes (2nd edition). Autophagy 2011, 7, 1273-1294. [CrossRef] [PubMed]

26. Burke, D.; Dawson, D.; Stearns, T. Methods in Yeast Genetics: A Cold Spring Harbor Laboratory Course Manual; CSHL Press: New York, NY, USA, 2000. 
27. Brendel, M.; Haynes, R.H. Interactions among genes controlling sensitivity to radiation and alkylation in yeast. Mol. Gen. Genet. MGG 1973, 125, 197-216. [CrossRef] [PubMed]

28. Brendel, M.; Khan, N.; Haynes, R. Common steps in the repair of alkylation and radiation damage in yeast. Mol. Gen. Genet. MGG 1970, 106, 289-295. [CrossRef] [PubMed]

29. Bradner, J.; Nevalainen, K. Metabolic activity in filamentous fungi can be analysed by flow cytometry. J. Microbial. Meth. 2003, 54, 193-201. [CrossRef]

30. Koistinen, K.M.; Soininen, P.; Venäläinen, T.A.; Häyrinen, J.; Laatikainen, R.; Peräkylä, M.; Tervahauta, A.I.; Kärenlampi, S.O. Birch PR-10c interacts with several biologically important ligands. Phytochemistry 2005, 66, 2524-2533. [CrossRef] [PubMed]

31. Kundu, S.; Roy, D. Structural study of biologically significant ligands with major birch pollen allergen Betv1 by docking and molecular dynamics simulation. Bioinformation 2010, 4, 326-330. [CrossRef] [PubMed]

32. Fister, A.S.; Mejia, L.C.; Zhang, Y.; Herre, E.A.; Maximova, S.N.; Guiltinan, M.J. Theobroma cacao L. pathogenesis-related gene tandem array members show diverse expression dynamics in response to pathogen colonization. BMC Genom. 2016, 17, 363. [CrossRef]

33. Hwang, J.; Song, W.; Hong, D.; Ko, D.; Yamaoka, Y.; Jang, S.; Yim, S.; Lee, H.; Khare, D.; Kim, K.; et al. Plant ABC Transporters Enable Many Unique Aspects of a Terrestrial Plant's Lifestyle. Mol. Plant. 2016, 9, $338-355$. [CrossRef] [PubMed]

34. Matuo, R.; Sousa, F.G.; Soares, D.G.; Bonatto, D.; Saffi, J.; Escargueil, A.E.; Larsen, A.K.; Henriques, J.A.P. Saccharomyces cerevisiae as a model system to study the response to anticancer agents. Cancer Chemoth. Pharm. 2012, 70, 491-502. [CrossRef] [PubMed]

35. Theresia, A.S.; Belinda, F.; Chitra, A.S.; Carpenter, E.P.; Vasundara, S.; Van Veen, H.; Balk, J. Structures and functions of mitochondrial ABC transporters. Biochem. Soc. Trans. 2015, 43, 943-951. [CrossRef]

36. Khan, A.A.; Quigley, J.G. Control of intracellular heme levels: Heme transporters and Heme oxygenases. Biochim. Biophys. Acta 2011, 1813, 668-682. [CrossRef] [PubMed]

37. Chloupkova, M.; Lebard, L.S.; Koeller, D.M. MDL1 is a high copy suppressor of ATM1: Evidence for a role in resistance to oxidative stress. J. Mol. Biol. 2003, 331, 155-165. [CrossRef]

38. Liesa, M.; Qiu, W.; Shirihai, O.S. Mitochondrial ABC transporters function: The role of ABCB10 (ABC-me) as a novel player in cellular handling of reactive oxygen species. Biochim. Biophys. Acta 2012, 1823, 1945-1957. [CrossRef] [PubMed]

39. Mroczek, S.; Kufel, J. Apoptotic signals induce specific degradation of ribosomal RNA in yeast. Nucleic Acids Res. 2008, 36, 2874-2888. [CrossRef] [PubMed]

40. Yorimitsu, T.; Zaman, S.; Broach, J.R.; Klionsky, D.J. Protein Kinase A and Sch9 Cooperatively Regulate Induction of Autophagy in Saccharomyces cerevisiae. Mol. Biol. Cell 2007, 18, 4180-4189. [CrossRef] [PubMed]

41. Wawrzycka, D.; Sobczak, I.; Bartosz, G.; Bocer, T.; Ułaszewski, S.; Goffeau, A. Vmr1p is a novel vacuolar multidrug resistance ABC transporter in Saccharomyces cerevisiae. FEMS Yeast Res. 2010, 10, 828-838. [CrossRef] [PubMed]

42. Adamis, P.D.B.; Panek, A.D.; Eleutherio, E.C.A. Vacuolar compartmentation of the cadmium-glutathione complex protects Saccharomyces cerevisiae from mutagenesis. Toxicol. Lett. 2007, 173, 1-7. [CrossRef] [PubMed]

43. Paumi, C.M.; Pickin, K.A.; Jarrar, R.; Herren, C.K.; Cowley, S.T. Ycf1p attenuates basal level oxidative stress response in Saccharomyces cerevisiae. FEBS Lett. 2012, 586, 847-853. [CrossRef] [PubMed]

44. Zhang, Y.; Qi, H.; Taylor, R.; Xu, W.; Liu, L.F.; Jin, S.V. The Role of Autophagy in Mitochondria Maintenance: Characterization of Mitochondrial Functions in Autophagy-Deficient S. cerevisiae Strains. Autophagy 2007, 3, 337-346. [CrossRef] [PubMed]

45. Yan, Q.; Qi, X.; Jiang, Z.; Yang, S.; Han, L. Characterization of a pathogenesis-related class 10 protein (PR-10) from Astragalus mongholicus with ribonuclease activity. Plant Physiol. Biochem. 2008, 46, 93-99. [CrossRef] [PubMed]

46. Madeo, F.; Herker, E.; Wissing, S.; Jungwirth, H.; Eisenberg, T.; Fröhlich, K.U. Apoptosis in yeast. Curr. Opin. Microbiol. 2004, 7, 655-660. [CrossRef] [PubMed]

47. Fabrizio, P.; Battistella, L.; Vardavas, R.; Gattazzo, C.; Liou, L.L.; Diaspro, A.; Dossen, J.W.; Gralla, E.B.; Longo, V.D. Superoxide is a mediator of an altruistic aging program in Saccharomyces cerevisiae. J. Cell. Biol. 2004, 166, 1055-1067. [CrossRef] [PubMed]

48. Desagher, S.; Martinou, J.C. Mitochondria as the central control point of apoptosis. Trends Cell Biol. 2000, 10, 369-376. [CrossRef] 
49. Kroemer, G.; Reed, J.C. Mitochondrial control of cell death. Nat Med. 2000, 6, 513-516. [CrossRef] [PubMed]

50. Basso, T.S.; Vita-Santos, E.; Marisco, G.; Pungartnik, C.; Brendel, M. Changes in cellular infrastructure after induced endoplasmic reticulum stress in Moniliophthora perniciosa. Mycologia 2016, 108l, 869-881. [CrossRef] [PubMed]

(c)

(c) 2018 by the authors. Licensee MDPI, Basel, Switzerland. This article is an open access article distributed under the terms and conditions of the Creative Commons Attribution (CC BY) license (http:/ / creativecommons.org/licenses/by/4.0/). 